\title{
Comparison of hepatitis B-infected and healthy individuals in terms of DMFT scores, endodontic treatment and extraction numbers: a cross-sectional study
}

\author{
Esma Sarıçam (iD *, Selen İnce Yusufoğlu \\ Department of Endodontics, Faculty of Dentistry, Ankara \\ Yıldırım Beyazıt University, Ankara, Turkey
}

\begin{abstract}
OвJECTIVE: This study aimed to determine the oral health of hepatitis B-infected individuals by comparing the DMFT index, which is recommended by the World Health Organization for assessing oral health, and the extraction and root canal treatment rates with those of healthy patients.
\end{abstract}

Materials and Method: The panoramic radiographs of 212 hepatitis B-infected and 213 healthy individuals aged 18-74 years who applied for dental treatment between January and June 2018 were evaluated. Using the panoramic radiographs, the numbers of teeth subject to root canal treatment (RCT), decay (D), extraction (M), and restorative and prosthetic treatments $(F)$ were recorded along with the total DMFT score. These rates were compared within and between the different age groups (18-34, 35-44, 4565 , and 66-74) and genders. The statistical analyses were performed using Mann-Whitney $U$ and Kruskal-Wallis tests. The level of significance was set to be $p<0.05$.

RESULTS: F and RCT rates in the healthy group and DMFT, $D$, and $M$ rates in the hepatitis $B$-infected group were found to be statistically significantly higher $(p<0.05)$. The DMFT scores of all age groups were statistically significantly higher in the hepatitis B-infected group compared to the healthy group $(p<0.05)$. No statistically significant difference was observed among age groups in terms of DMFT scores within the healthy and hepatitis B-infected groups $(p>0.05)$.

Conclusion: When compared to healthy individuals, the DMFT, $D$, and $M$ rates of individuals infected with hepatitis $B$ were found to be higher, but the F and RCT rates were lower. Hepatitis $B$-infected individuals should be motivated to improve their oral health.

KEYwORDS: Dental caries; endodontics; hepatitis B; tooth extraction

Received: November 29, 2020; Accepted: January 31, 2021

${ }^{*}$ Corresponding author: Dr. Esma Sarıcam, Department of Endodontics,

Faculty of Dentistry, Ankara Yıldırım Beyazıt University, Ayvalı Mah., 150.

Sokak, 06010, Etlik, Ankara, Turkey

E-mail: esaricam@ybu.edu.tr.dt.esmasaricam@gmail.com
Citation: Sarıçam E, İnce Yusufoğlu S. Comparison of hepatitis B-infected and healthy individuals in terms of DMFT scores, endodontic treatment and extraction numbers: a cross-sectional study. Acta Odontol Turc 2021;38(3):56-61

EdıToR: Güven Kayaoğlu, Gazi University, Ankara, Turkey

CoPYRIGHT: (C) 2021 Sarıçam \& Ince Yusufoğlu. This work is licensed under a Creative Commons Attribution License. Unrestricted use, distribution, and reproduction in any medium are permitted provided the original author and source are credited.

FunDING: None declared.

CONFLICT OF INTEREST: The authors declare no conflict of interest related to this study.

\section{INTRODUCTION}

Hepatitis B infection has been reported to be the most frequent cause of chronic hepatitis, liver cirrhosis, and hepatocellular carcinoma diseases. ${ }^{1,2}$ As a result, hepatitis $B$ infection is considered to be a major public health problem. ${ }^{3}$ It has been reported that more than two billion people have been infected with hepatitis $B$ throughout the world, of whom 350-400 million have chronic cases of infection. , $^{4}$ In Turkey, it was reported that $0.87 \%$ of patients applying for dental treatment had hepatitis $\mathrm{B}$ infection. ${ }^{6}$

The hepatitis B virus is highly contagious, and the common modes of transmission are the use of intravenous medication, unprotected sexual intercourse with multiple partners, exposure to the virus during medical interventions, such as dialysis and surgical operations, accidental injuries with a contaminated needle, and vertical transmission from

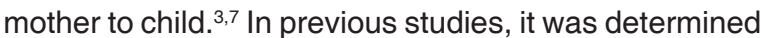
that dental treatment procedures are also a high-risk factor for the transmission of hepatitis $B$ virus between patients. ${ }^{8-10}$ Moreover, the widespread use of sharp instruments contaminated with the patient's blood and saliva in the dentistry practice increases the possibility of dental personnel's injury with instruments infected with hepatitis $B .^{10}$ 
The DMFT index is the most widely used epidemiologic measurement for monitoring decay distribution trends, and it is recommended by WHO for assessing oral health and determining the number and density of decays. ${ }^{11}$ The DMFT method is based on a calculation of the sum of the numbers of decayed (D), extracted/missing $(\mathrm{M})$, and filled $(\mathrm{F})$ permanent teeth via intraoral examination of an adult (dmft for deciduous teeth).

Root canal treatment (RCT) is an option for addressing the long-term comfort and esthetic of the patient that allows for teeth with pulpal or periodontal diseases because of decay or trauma to be kept. ${ }^{12}$ The tooth to be subjected to canal treatment must be suitable for restoration. However, for teeth with unrestorable advanced decay, extraction is indicated rather than canal treatment. ${ }^{13} \mathrm{~A}$ canal treatment applied to a tooth can be detected in a radiographic examination rather than an intraoral one. Dental panoramic radiograph is an imaging method that is widely used by dentists in routine dental examinations; this method allows for the examination of the maxillary and mandibular bones and anatomic structures, as well as the alveolar bone and all the teeth. ${ }^{14}$

Dental personnel are at risk of accidental injuries during the dental treatment of hepatitis B-infected patients (HIPs). Dental treatment histories are common in the anamneses of HIPs, and this suggests that healthy individuals receiving dental treatment are at risk even if sterilization and disinfection measures have been taken. Improving the oral health of this patient group would decrease these risks and increase their quality of life. Determining the DMFT scores of the infected patient group is a step further in this process.

In a literature review, no study determining the DMFT index of hepatitis B-infected individuals was found. Using panoramic radiographs of hepatitis B-infected and healthy individuals, the aim of the present study was to compare the numbers of teeth with RCT, D, M, and $F$ rates and the DMFT scores by gender and age group. The null hypotheses were as follows: (1) There are no differences between the healthy and hepatitis $\mathrm{B}$-infected individuals in terms of RCT, D, M, and F rates and DMFT scores. (2) There are no differences between the healthy and hepatitis $\mathrm{B}$-infected individuals in terms of RCT, D, M, and F rates and DMFT scores for gender and age groups. (3) There are no differences between different age groups in healthy and hepatitis B-infected groups in terms of RCT, D, M, and F rates and DMFT scores.

\section{Materials AND Method}

Approval for the present study was obtained from the ethics committee of Ankara Yıldırım Beyazıt University (Decision date and number: 21.11.2018-70, research number: 2018-396). Among the patients applying for dental treatment between January and June 2018,
212 HIPs and 213 healthy individuals were randomly selected. Patients between 18 and 74 years old who had panoramic radiographs and no systemic diseases were included in the study. The panoramic radiographs of these patients were recorded together with their ages and genders.

By using the recorded radiographs, each of the individuals was evaluated with the DMFT index developed by WHO in 1997. The third molar teeth were excluded from the evaluations, and the calculations were performed on 28 teeth per patient. The numbers of decayed teeth (D), extracted or missing teeth (M), and teeth with composite/amalgam filling or crown restoration $(F)$ were determined. These rates were calculated, and the DMFT score was found by calculating the sum of these values. The number of teeth with RCT was also recorded for each individual. The healthy subjects and HIPs were divided into additional groups based on age (18-34, 35-44, 45-65, and $66-74)$ and gender. The $D, M, F$, and RCT rates and DMFT scores were compared between healthy and HIP groups by age and gender. The age groups within the healthy and HIP groups were also compared in terms of $\mathrm{D}, \mathrm{M}, \mathrm{F}$, and $\mathrm{RCT}$ rates and DMFT scores.

\section{Statistical analysis}

Statistical analyses were performed using SPSS software version 22.0 (SPSS Inc., Chicago, IL, USA). The Kolmogorov-Smirnov test was used for the assumption of normality. The data revealed a nonnormal distribution for the groups. The statistical analyses were performed using Mann-Whitney $U$ and Kruskal-Wallis tests. The level of significance was set to be $p<0.05$. The Mann-Whitney $U$ test was used in comparing the healthy and hepatitis B-infected groups by age group, gender, and total group in terms of DMFT scores and D, M, F, and RCT rates. The Kruskal-Wallis test was used to compare the age groups within the healthy and hepatitis B-infected groups in terms of these same variables. If there was a statistically significant difference after the Kruskal-Wallis test, Mann-Whitney $\mathrm{U}$ tests with Bonferroni correction were performed to determine a statistically significant difference with a significance level of $p<0.0125$.

\section{Results}

\section{Comparing the healthy and HIP groups}

In the HIP group, the DMFT scores and the $D$ and $M$ rates were found to be statistically significantly higher than those in the healthy group $(p<0.001)$ (Table 1; Figure 1 ); however, the $F$ and RCT rates were statistically significantly lower $(p<0.001$; Table 1 ; Figure 1$)$. When comparing the HIP-female and HIP-male groups to the healthy-female and healthy-male groups, respectively, the DMFT scores and the $D$ and $M$ rates were found to be statistically significantly higher $(p<0.001)$, but the $F$ and RCT rates were found to be lower $(p<0.05)$ in the HIP group for both genders (Table 1). 
Table 1. Comparison of healthy and HIP groups in terms of DMFT, D, M, F, and RCT values for age groups and genders

\begin{tabular}{|c|c|c|c|c|c|c|c|c|}
\hline & \multirow{2}{*}{ Groups } & \multicolumn{3}{|c|}{ Healthy } & \multicolumn{3}{|c|}{ HIP } & \multirow{2}{*}{ P value ${ }^{m}$} \\
\hline & & $\mathbf{n}$ & Median & IQR & $\mathbf{n}$ & Median & IQR & \\
\hline & DMFT & 213 & 7.00 & 6 & 212 & 10.00 & 28 & 0.000 \\
\hline & $M$ & & 1.00 & 3 & & 4.00 & 26 & 0.000 \\
\hline & $F$ & & 5.00 & 6 & & 3.00 & 17 & 0.000 \\
\hline \multirow{8}{*}{ 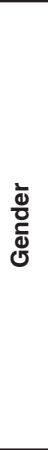 } & DMFT & & 7.00 & 5 & & 10.50 & 7 & 0.000 \\
\hline & D & & 0.00 & 1 & & 2.00 & 4 & 0.000 \\
\hline & $M$ & & 1.00 & 8 & & 4.00 & 5 & 0.000 \\
\hline & $\mathrm{F}$ & & 5.00 & 20 & & 4.00 & 5 & 0.023 \\
\hline & D & & 0.00 & 0 & & 2.00 & 2 & 0.000 \\
\hline & $M$ & & 1.00 & 8 & & 3.50 & 23 & 0.000 \\
\hline & $\mathrm{F}$ & & 5.00 & 6 & & 3.00 & 4 & 0.009 \\
\hline & RCT & & 1.00 & 3 & & 0.00 & 1 & 0.000 \\
\hline \multirow{18}{*}{ 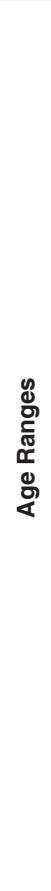 } & $18-34$ & 81 & & & 42 & & & \\
\hline & DMFT & & 8.00 & 5 & & 9.00 & 17 & 0.013 \\
\hline & D & & 0.00 & 1 & & 4.00 & 4 & 0.000 \\
\hline & $M$ & & 2.00 & 4 & & 1.00 & 3 & 0.130 \\
\hline & $\mathrm{F}$ & & 5.00 & 5 & & 5.00 & 6 & 0.199 \\
\hline & $\mathrm{RCT}$ & & 1.00 & 3 & & 0.50 & 2 & 0.169 \\
\hline & $45-64$ & 59 & & & 95 & & & \\
\hline & DMFT & & 6.00 & 6 & & 11.00 & 10 & 0.000 \\
\hline & D & & 0.00 & 0 & & 1.00 & 2 & 0.000 \\
\hline & $M$ & & 1.00 & 2 & & 5.00 & 5 & 0.000 \\
\hline & $\mathrm{F}$ & & 5.00 & 8 & & 3.00 & 5 & 0.016 \\
\hline & RCT & & 1.00 & 2 & & 0.00 & 1 & 0.000 \\
\hline & $65-74$ & 27 & & & 11 & & & \\
\hline & DMFT & & 6.00 & 7 & & 12.00 & 13 & 0.018 \\
\hline & D & & 0.00 & 1 & & 0.00 & 2 & 0.203 \\
\hline & $M$ & & 0.00 & 3 & & 5.00 & 8 & 0.000 \\
\hline & $\mathrm{F}$ & & 4.00 & 7 & & 2.00 & 9 & 0.549 \\
\hline & RCT & & 0.00 & 2 & & 0.00 & 1 & 0.531 \\
\hline
\end{tabular}

${ }^{m}$ Mann Whitney U. IQR: Interquartile range, D: decayed, M: missed, F: filled and RCT: root canal treatment. DMFT: Total value of $D, M, F$

In the 18-34 age group, the DMFT and D rates were found to be higher in the HIP group ( $p<0.05$ ), whereas no statistically significant difference was observed in terms of the M, F, and RCT rates $(p>$ 0.05 ; Table 1). In the 35-44 and 45-64 age groups, the DMFT scores and the $D$ and $M$ rates were found to be statistically significantly higher in the HIP group $(p<$ 0.05 ), whereas the RCT and F rates were found to be higher in the healthy group ( $<<0.001$; Table 1$)$. In the 65-74 age group, the DMFT and M rates were found to be statistically significantly higher in the HIP group ( $p$ $<0.05)$, but no statistically significant differences were found in terms of the $D, F$, and RCT rates ( $p>0.05$; Table 1).

\section{Intragroup comparisons by age group}

In the healthy group, no statistically significant difference was found among the age groups in terms of the DMFT scores and the D and $F$ rates $(p>0.05$; Table 2). In this group, the $M$ rates in the 18-34 age group were found to be statistically significantly higher than in the 35-44 and 45-64 age groups ( $p<0.0125)$, and similar to the rates of the 65-74 group ( $p>0.0125)$. However, no statistically significant difference was found among the 35-44, 45-64, and 65-74 age groups in the healthy group ( $p>0.0125)$ (Table 2) for the $M$ rates. The RCT rates in the 35-44 age group were found to be statistically significantly higher than those in the 65-74 age group $(p<0.0125)$. No statistically 
significant difference was found between the other age groups in the healthy group ( $p>0.0125$; Table 2$)$ in terms of the RCT rates.

In the HIP group, no statistically significant difference was found among the age groups in terms of DMFT, F, and RCT rates ( $p>0.05$; Table 2). In the HIP group, however, the $\mathrm{M}$ rates of the 18-34 age group were found to be lower than those of the other three age groups $(p<0.0125)$. The $M$ rates of the $35-44$ age group were found to be statistically significantly lower than those in the 45-64 age group ( $<<0.0125$; Table 2). No statistically significant difference was found between the other age groups in the HIP group $(p>$ $0.0125)$ for the $M$ rates. The $D$ rates for the 18-34 age group were the highest $(p<0.0125)$ among the age groups in the HIP group. However, the D rates were found to be statistically similar among the other three age groups in the HIP group ( $p>0.0125$; Table 2$)$.
Healthy $\quad$ Hepatitis-B infected

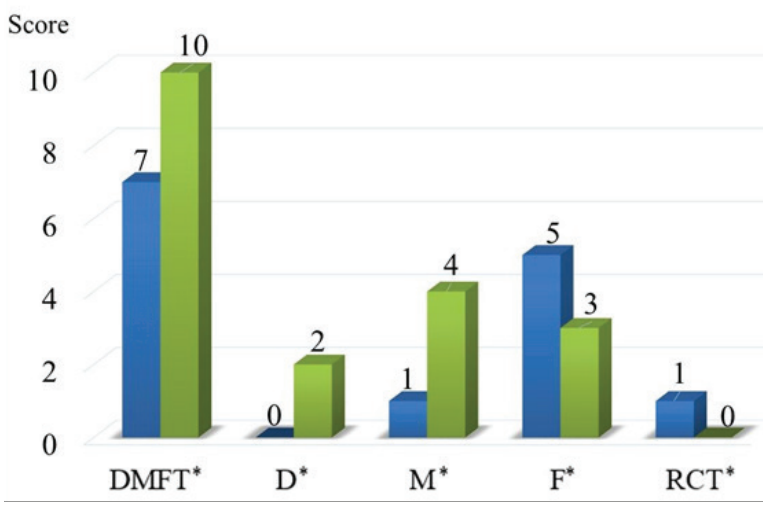

Figure 1. Comparison of the median values between healthy and HIP groups for DMFT, D, M, F, and RCT. (*) marks statistically significant difference between the groups.

Table 2. Comparison of age groups within the healthy and HIP groups in terms of DMFT, D M, F and RCT

\begin{tabular}{|c|c|c|c|c|c|c|c|}
\hline \multirow{2}{*}{ Groups } & \multirow{2}{*}{ Age ranges } & \multicolumn{3}{|c|}{ Healthy } & \multicolumn{3}{|c|}{ HIP } \\
\hline & & Median & IQR & P value ${ }^{\mathrm{K}}$ & Median & IQR & P value $^{\mathrm{K}}$ \\
\hline \multirow{4}{*}{ DMFT } & $18-34$ & 8.00 & 5 & \multirow{4}{*}{0.711} & 9.00 & 17 & \multirow{4}{*}{0.190} \\
\hline & $35-44$ & 7.00 & 5 & & 9.00 & 7 & \\
\hline & $45-64$ & 6.00 & 6 & & 11.00 & 10 & \\
\hline & $65-74$ & 6.00 & 7 & & 12.00 & 13 & \\
\hline \multirow{4}{*}{ D } & $18-34$ & 0.00 & 1 & \multirow{4}{*}{0.120} & $4.00^{A}$ & 4 & \multirow{4}{*}{0.000} \\
\hline & $35-44$ & 0.00 & 0 & & $2.00^{\mathrm{B}}$ & 2 & \\
\hline & $45-64$ & 0.00 & 0 & & $1.00^{B}$ & 2 & \\
\hline & $65-74$ & 0.00 & 1 & & $0.00^{\mathrm{B}}$ & 2 & \\
\hline \multirow{4}{*}{ M } & $18-34$ & $2.00^{A}$ & 4 & \multirow{4}{*}{0.006} & $1.00^{A}$ & 3 & \multirow{4}{*}{0.000} \\
\hline & $35-44$ & $1.00^{\mathrm{B}}$ & 2 & & $3.00^{\mathrm{B}}$ & 5 & \\
\hline & $45-64$ & $1.00^{\mathrm{B}}$ & 2 & & $5.00^{c}$ & 5 & \\
\hline & $65-74$ & $0.00^{\mathrm{A}, \mathrm{B}}$ & 3 & & $5.00^{\mathrm{B}, \mathrm{C}}$ & 8 & \\
\hline \multirow{4}{*}{$\mathbf{F}$} & $18-34$ & 5.00 & 5 & \multirow{4}{*}{0.459} & 5.00 & 6 & \multirow{4}{*}{0.754} \\
\hline & $35-44$ & 5.00 & 6 & & 3.00 & 4 & \\
\hline & $45-64$ & 5.00 & 8 & & 3.00 & 5 & \\
\hline & $65-74$ & 4.00 & 7 & & 2.00 & 9 & \\
\hline \multirow{4}{*}{ RCT } & 18-34 & $1.00^{\mathrm{A}, \mathrm{B}}$ & 3 & \multirow{4}{*}{0.026} & 0.50 & 2 & \multirow{4}{*}{0.107} \\
\hline & $35-44$ & $1.50^{A}$ & 2 & & 0.00 & 1 & \\
\hline & $45-64$ & $1.00^{\mathrm{A}, \mathrm{B}}$ & 2 & & 0.00 & 1 & \\
\hline & $65-74$ & $0.00^{\mathrm{B}}$ & 2 & & 0.00 & 1 & \\
\hline
\end{tabular}

${ }^{k}$ Kruskal-Wallis. IQR: Interquartile range, D: decayed, M: missed, F: filled and RCT: root canal treatment. DMFT: Total value of D, M, F. Different superscript letters mean significant difference within same column for each group ( $M$ and RCT scores in the healthy group; $D$ and $M$ scores in the HIP group)

\section{Discussion}

This study aimed to compare the oral health of HIPs and healthy patients by determining their DMFT scores and $D, M, F$, and $R C T$ rates. The main result of the present study was that, when compared to the healthy individuals, the HIPs had higher DMFT scores and $D$ and $M$ rates. However, the $F$ and RCT rates were found to be higher in the healthy group. There was no significant difference between the age groups in the healthy group in terms of DMFT scores and D and F rates or among the age groups in the HIP group in terms of DMFT scores and F and RCT rates. Therefore, the hypotheses were partially accepted.

In the present study, the DMFT scores were analyzed separately from the $D, M$, and $F$ rates in both groups. A low DMFT score indicates better oral health of the patient. When compared to the healthy group, the higher DMFT scores of the HIPs in total and in comparisons between the age groups and genders suggests worse oral health in this group.

Decay is defined as a disease and is represented by the $D$ in the DMFT index. In this aspect, the DMFT detects both currently existing (D) and treated (M, F) diseases. ${ }^{15}$ The higher rate of $\mathrm{D}$ (currently existing 
disease) in the HIP group could show that the need for dental treatment was higher for the HIP group compared to the healthy patients. Further, the $\mathrm{F}$ rate was found to be higher in the healthy group, but the $M$ rates were higher in the HIP group. The higher M rates in the HIP group suggest that the patients applied for dental treatment after the conditions of the teeth passed the restorable level, and extraction became necessary. In previous studies, it was reported that the increase in the number of RCTs was related to the decrease in the number of extractions. ${ }^{16-18}$ Similarly, it was determined in the present study that, when compared to the healthy group, the $\mathrm{M}$ rates were found to be higher and the RCT rates to be lower in the HIP group. Several factors, such as larger periapical lesions, teeth with severe mobility, and severe dental structure loss, can explain the contraindication of RCT. The higher number of extractions instead of RCT could indicate that there are more teeth with these findings in the HIP group. In this study, the F and RCT rates were lower and the $M$ rates were higher in the HIP group compared to the corresponding rates for the healthy group. It was determined that dentists may be unwilling to implement dental treatment on HIPs because of the infection risk. ${ }^{19}$ It was thought that this may result in radical treatment decisions for HIPs instead of time-consuming options such as restorative and prosthetic treatments, or RCT. Further studies examining the impact of dentists' attitudes on extraction indications among HIPs would be informative.

In the HIP group, no difference was observed among the age groups in terms of DMFT scores and $\mathrm{F}$ and RCT rates. The RCT rates were similar for all age groups in the HIP group. In this group, the M rates of the 18-34 age group were found to be lower than those in the other age groups, whereas the $M$ rates of the 35-44 age group were found to be lower than those in the 45-64 age group. It was determined that the number of missing teeth changed aggressively in a negative direction since the rate of extraction increased as age advanced. The increased $D$ rates in the younger population of the HIP group also indicate that the need for treatment is higher in this group, as the $D$ rate is indicative of a currently existing disease..$^{15}$

In Turkey, the DMFT score has previously been found to be 6.72 , previously. ${ }^{20}$ In this study, the median DMFT score was 7 in the healthy group, which is similar to the previously reported score. The DMFT scores and $D$ and $F$ rates were similar among the age groups in the healthy group. In the healthy group, the $M$ rates in the 18-34 age group were higher than those in the $35-44$ and $45-64$ age groups and similar to those of the $65-74$ age group. The oral self-care of Turkish university students (aged 17-27) was reported to be lower than the corresponding levels in industrialized countries. ${ }^{21}$ Specifically, a previous study claimed that individuals aged 18-25 years had less routine dental visits and worse eating habits. These factors may be responsible for the increased $M$ rates in the 18-34 age group. ${ }^{22}$ Younger adults should be motivated to practice oral self-care, attend routine dental visits, and consume non-cariogenic diets. Further studies evaluating oral hygiene habits and diet routines for different age groups could be helpful in this respect.

This study has some limitations. Only patients who had panoramic radiographs were included in this study, and data were provided only for patients applying within a time period. Furthermore, the DMFT and RCT rates were calculated using the panoramic radiographs of the patients in the HIP and healthy groups. Generally, DMFT is calculated by determining the D, M, and F rates with an intraoral examination. In the present study, the use of panoramic radiographs allowed for the imaging of all the teeth in the mouth. $\mathrm{M}$ and $\mathrm{F}$ rates do not vary between intraoral examination and panoramic radiography. RCT, however, can be determined only through the radiography method. Nevertheless, radiography might be inadequate for detecting decays in the initial phase. Despite these limitations, the DMFT scores of the HIP group were found to be very high. In suspicious cases, the existing periapical radiographs of the patients were utilized. Although, the decays in the initial phase might have been missed when using panoramic radiography, both groups were examined under equal conditions using the same method.

In HIPs, a lower health-related quality of life and higher risk of depression have been found compared to the general population. ${ }^{23,24}$ These factors have been reported to be associated with being less likely to comply and follow up with medical treatment in HIPs. ${ }^{25}$ These factors may also lead HIPs to not attend as required to their oral health. For this purpose, medical specialists such as gastroenterologists or infectious disease specialists, who regularly follow up with these patients, might call their attention to their oral care and the importance of dental examinations. The HIPs should be motivated to maintain a good level of oral hygiene

\section{ConCLusion}

Regardless of age and gender, the DMFT scores of the HIPs were higher than those of the healthy patients. The HIPs should be motivated to maintain a good level of oral hygiene and increase their frequency of dental visits.

\section{ACKNOWLEDGMENTS}

The authors thank Dr. Mustafa Güngörmüş for his assistance in the statistical analysis of this study. A part of the data in this article was presented as oral presentation at the '1st International Dental and Oral Infections Congress' (7-9 September 2018, Sakarya, Turkey) 


\section{References}

1. Zuckerman AJ. More than third of world's population has been infected with hepatitis B virus. BMJ 1999;318:1213.

2. Sinn DH, Paik SW, Kang P, Kil JS, Park SU, Lee SY, et al. Disease progression and the risk factor analysis for chronic hepatitis C. Liver Int 2008;28:1363-9.

3. Mahboobi N, Porter SR, Karayiannis $\mathrm{P}$, Alavian SM. Dental treatment as a risk factor for hepatitis $B$ and $C$ viral infection. A review of the recent literature. J Gastrointestin Liver Dis 2013;22:79-86.

4. Marcellin P. Hepatitis B and hepatitis C in 2009. Liver Int 2009;29 Suppl 1:1-8.

5.Luksamijarulkul P, Piroonamornpun P, Triamchaisri SK. Hepatitis B seromarkers, hepatitis $\mathrm{C}$ antibody, and risk behaviors in married couples, a bordered province of western Thailand: Hepatitis B seromarkers, hepatitis $\mathrm{C}$ antibody, and risk behaviors. Hepat Mon 2011;11:273-7.

6. Hoşgör H. Kocaeli Üniversitesi Diş Hekimliği Fakültesine başvuran hastalarda hepatit $A, B, C$ ve HIV enfeksiyon sıklığının değerlendirilmesi. Acta Odontol Turc 2020;37:36-41.

7. Khandelwal V, Khandelwal S, Gupta N, Nayak UA, Kulshreshtha $\mathrm{N}$, Baliga S. Knowledge of hepatitis $\mathrm{B}$ virus infection and its control practices among dental students in an Indian city. Int $\mathrm{J}$ Adolesc Med Health 2017;30:/j/ijamh.2018.30.issue-5/ijamh-2016-0103/ ijamh-2016-0103.xml.

8. Molla S, Munshea A, Nibret E. Seroprevalence of hepatitis B surface antigen and anti HCV antibody and its associated risk factors among pregnant women attending maternity ward of Felege Hiwot Referral Hospital, northwest Ethiopia: a cross-sectional study. Virol J 2015;12:204.

9. Baha W, Foullous A, Dersi N, They-they TP, El alaoui K, Nourichafi $\mathrm{N}$, et al. Prevalence and risk factors of hepatitis $\mathrm{B}$ and $\mathrm{C}$ virus infections among the general population and blood donors in Morocco. BMC Public Health 2013;13:50.

10. Al-Amad SH. Prevalence of hepatitis $B, C$, and HIV among patients attending a teaching dental hospital. A 7-year retrospective study from the United Arab Emirates. Saudi Med J 2018;39:500-5.

11. Radic M, Benjak T, Vukres VD, Rotim Z, Zore IF. Presentation of DMFT/dmft Index in Croatia and Europe. Acta Stomatol Croat 2015;49:275-84.

12. Torabinejad $M$, Parirokh $M$, Dummer $P M H$. Mineral trioxide aggregate and other bioactive endodontic cements: an updated overview - part II: other clinical applications and complications. Int Endod J 2018;51:284-317.

13. Sidana S, Mistry Y, Gandevivala A, Motwani N. Evaluation of the Need for Antibiotic Prophylaxis During Routine Intra-alveolar Dental Extractions in Healthy Patients: A Randomized Double-Blind Controlled Trial. J Evid Based Dent Pract 2017;17:184-9.

14. Chugh NK, Bhattacharyya J, Das S, Ghosh S, Dutta K, Goel P. Use of digital panoramic radiology in presurgical implant treatment planning to accurately assess bone density. J Prosthet Dent 2016;116:200-5.e1.

15. Frencken JE, Sharma P, Stenhouse L, Green D, Laverty D, Dietrich T. Global epidemiology of dental caries and severe periodontitis - a comprehensive review. J Clin Periodontol 2017;44 Suppl 18:S94-S105.

16. Bjorndal L, Laustsen $\mathrm{MH}$, Reit C. Root canal treatment in Denmark is most often carried out in carious vital molar teeth and retreatments are rare. Int Endod J 2006;39:785-90

17. Bjorndal L, Reit $C$. The annual frequency of root fillings, tooth extractions and pulp-related procedures in Danish adults during 19772003. Int Endod J 2004;37:782-8

18. Norderyd O, Koch G, Papias A, Kohler AA, Helkimo AN, Brahm CO, et al. Oral health of individuals aged 3-80 years in Jonkoping, Sweden during 40 years (1973-2013). II. Review of clinical and radiographic findings. Swed Dent J 2015;39:69-86.

19. Khalil $\mathrm{H}$. Willingness of Saudi dental professionals to treat Hepatitis $B$ virus-infected patients. Niger J Clin Pract 2015;18:247-50.

20. Tanık A. Evaluation of the relationship of CPITN and DMFT index of adult patients in Turkey with their demographic characteristics: an epidemiological study. Biotechnology \& Biotechnological Equipment 2019;33:1626-34.

21. Kırtıloğlu T, Yavuz ÜS. An assessment of oral self-care in the student population of a Turkish university. Public Health 2006;120:9537.

22. Akarslan ZZ, Sadik B, Sadik E, Erten H. Dietary habits and oral health related behaviors in relation to DMFT indexes of a group of young adult patients attending a dental school. Med Oral Patol Oral Cir Bucal 2008;13:E800-7.

23. Vu TTM, Le TV, Dang AK, Nguyen LH, Nguyen BC, Tran BX, et al. Socioeconomic Vulnerability to Depressive Symptoms in Patients with Chronic Hepatitis B. Int J Environ Res Public Health 2019;16:255.

24. Keskin G, Gumus AB, Orgun F. Quality of life, depression, and anxiety among hepatitis B patients. Gastroenterol Nurs 2013;36:34656.

25. Alian S, Masoudzadeh A, Khoddad T, Dadashian A, Ali Mohammadpour R. Depression in hepatitis B and C, and its correlation with hepatitis drugs consumption (interfron/lamivodin/ribaverin). Iran J Psychiatry Behav Sci 2013;7:24-9.

\section{Hepatit B enfekte ve sağlıklı bireylerin DMFT skorları, endodontik tedavi ve çekim sayıları açısından karşılaştırılması: kesitsel bir çalışma}

\section{Özet}

AmAÇ: Bu çalışmada, hepatit B enfekte bireylerin Dünya Sağlık Örgütü'nün ağız sağlığını değerlendirmek için önerdiği DMFT indeksi ve diş çekimi ve kanal tedavisi sayılarını sağlıklı bireylerle karşılaştırarak hepatit B enfekte bireylerin ağız sağlığını belirlemek amaçlandı.

GeREÇ VE YönTEM: Ocak-Haziran 2018 tarihleri arasında diş tedavisi için başvuran 18-74 yaş arası 212 hepatit $B$ enfekte ve 213 sağlıklı bireyin panoramik radyografları kaydedildi. Panoramik radyograflar değerlendirilerek hastalardaki kanal tedavili (KT), çürük (D), çekilmiş (M) ve restoratif ve protetik tedavileri $(F)$ diş sayısı ve toplam değerler (DMFT) kaydedildi. Bu değerler, cinsiyetler içinde ve farklı yaş grupları (18-34, 35-44, 45-65 ve 66-74) arasında ve içinde olmak üzere karşılaştırıldı. İstatistiksel analizler Mann-Whitney U ve Kruskal-Wallis testleri kullanılarak yapıldı. Anlamlılık seviyesi $\mathrm{p}<0.05$ olarak belirlendi.

BuLguLAR: Sağlıklı grupta F ve KT değerleri, hepatit B enfekte grupta DMFT, D ve M değerleri istatistiksel olarak anlamlı düzeyde daha yüksek bulundu $(p<0.05)$. Tüm yaş gruplarında DMFT değerleri, sağlıklı gruba göre hepatit B enfekte grupta istatistiksel olarak anlamlı düzeyde daha yüksekti $(p<0.05)$. Sağlıklı ve hepatit B enfekte grupları içinde DMFT değerleri açısından farklı yaş grupları arasında istatistiksel olarak anlamlı bir fark gözlenmedi ( $p$ > 0.05).

Sonuç: Hepatit B enfekte grupta sağlıklı gruba göre DMFT, $D$ ve $M$ değerleri daha yüksek, $F$ ve $K T$ değerleri daha düşük bulundu. Hepatit B enfekte bireyler ağız sağlığını iyileştirmek açısından motive edilmelidir.

Anahtar Kelimeler: Diş çekimi, diş çürüğü, endodonti, hepatit $B$ virüsü 